\title{
On the Psychology of Confessions
}

\author{
Does Innocence Put Innocents at Risk?
}

\author{
Saul M. Kassin
}

Williams College

The Central Park jogger case and other recent exonerations highlight the problem of wrongful convictions, $15 \%$ to $25 \%$ of which have contained confessions in evidence. Recent research suggests that actual innocence does not protect people across a sequence of pivotal decisions: (a) In preinterrogation interviews, investigators commit falsepositive errors, presuming innocent suspects guilty; (b) naively believing in the transparency of their innocence, innocent suspects waive their rights; (c) despite or because of their denials, innocent suspects elicit highly confrontational interrogations; (d) certain commonly used techniques lead suspects to confess to crimes they did not commit; and (e) police and others cannot distinguish between uncorroborated true and false confessions. It appears that innocence puts innocents at risk, that consideration should be given to reforming current practices, and that a policy of videotaping interrogations is a necessary means of protection.

n 1989, a female jogger was beaten senseless, raped, and left for dead in New York City's Central Park. Her skull had multiple fractures, her eye socket was crushed, and she lost three quarters of her blood. She managed to survive, but she was and still is completely amnesic regarding the incident (Meili, 2003). Soon thereafter, on the basis of police-induced confessions taken within 48 hours, five African and Hispanic American boys, 14 to 16 years old, were convicted of the attack and sentenced to prison. The crime scene betrayed a bloody, horrific act for which there were no physical traces of the defendants. Yet it was easy to understand why detectives aggressively interrogated the boys, at least some of whom were "wilding" in the park that night. It was also easy to understand why the boys were prosecuted and convicted. Four of the confessions were videotaped and presented at trial. The tapes were compelling, as every one of the defendants described in vivid - though often erroneousdetail how the jogger was attacked, when, where, and by whom, and the role that he played. One boy stood up and reenacted the way he allegedly pulled off the jogger's running pants. A second said he felt pressured by peers to take part in his "first rape," expressing remorse and promising that it would not happen again. Together, the taped confessions persuaded police, prosecutors, two trial juries, a city, and a nation (for details, see Sullivan, 1992).
Thirteen years later, Matias Reyes, in prison for three rapes and a murder committed subsequent to the jogger attack, stepped forward with a voluntary confession. He claimed that he was the Central Park jogger rapist and that he had acted alone. Reinvestigating the case, the Manhattan district attorney's office questioned Reyes and discovered that he had accurate, privileged, and independently corroborated knowledge of the crime and crime scene. DNA testing further revealed that the semen samples originally recovered from the victim's body and socks-which had conclusively excluded the boys as donors-belonged to Reyes (prosecutors had argued that just because police did not capture all the perpetrators in the alleged gang rape did not mean they did not get some of them). In December 2002, the defendants' convictions were vacated. The Central Park jogger case now stands as a shocking tale of five false confessions resulting from a single investigation (Kassin, 2002; New York v. Wise et al., 2002; Saulny, 2002).

Despite its historic symbolic value and notoriety, the jogger case is not unique. Notwithstanding debates and disputes over prevalence numbers (e.g., Bedau \& Radelet, 1987; Cassell, 1999; Leo \& Ofshe, 2001; Markman \& Cassell, 1988), the incidence of false confessions is unknown. Still, there are a disturbing number of known cases in which defendants confess and retract the confessions but are convicted at trial and sometimes sentenced to deathonly later to be exonerated (Drizin \& Leo, 2004; Gross, Jacoby, Matheson, Montgomery, \& Patel, 2004; Gudjonsson, 1992, 2003; Kassin, 1997; Kassin \& Wrightsman, 1985; Leo \& Ofshe, 1998; Scheck, Neufeld, \& Dwyer, 2000). As the number of exonerations accumulates, revealing the mere tip of an iceberg in miscarriages of justice (Gross et al., 2004), the Innocence Project (www innocenceproject.org) and other researchers have come to realize the valuable role that psychological science can play in the study and prevention of wrongful convictions. First and foremost, it is clear that eyewitness misidentifications, found in nearly three quarters of these cases, are the most common source of error and that eyewitness psychologists have had an enormous impact identifying the problems and proposing reforms to minimize error (see Loftus, 1979;

Correspondence concerning this article should be addressed to Saul M Kassin, Department of Psychology, Bronfman Science Center, Williams College, Williamstown, MA 01267. E-mail: Saul.M.Kassin@williams .edu 


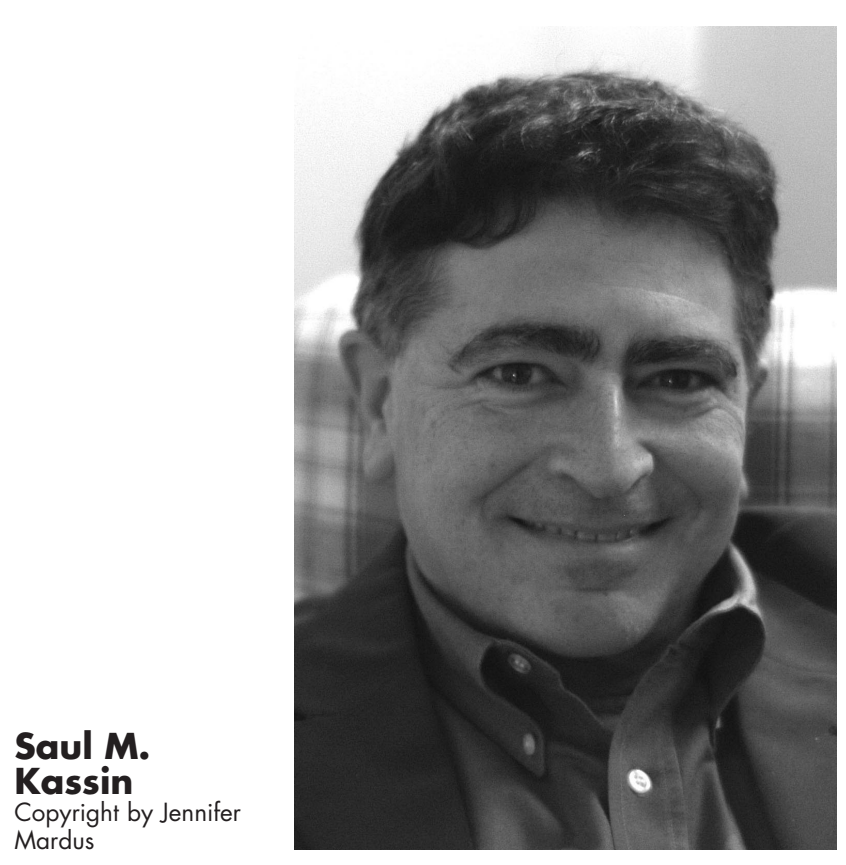

Wells et al., 2000). Although other problems involve limitations and flaws in various forensic sciences (see Faigman, Kaye, Saks, \& Sanders, 2002), the focus of this article is on a second psychologically based problem that has reared its ugly head: that $15 \%$ to $25 \%$ of DNA-exonerated innocent defendants had confessed prior to their trials (see www.innocenceproject.org).

The problem of false confessions is complex and multifaceted, and it indicates that there may be holes in the various "safety nets" built into the criminal justice system. This article is designed with three objectives in mind. In light of the high-profile wrongful convictions, many discovered via newly available DNA tests, a wealth of new empirical research, post-9/11 interest in military and terrorist interrogations, and developments in law on the admissibility of scientific and psychological forensic testimony, the first objective is to update an earlier review in this journal on the psychology of confession evidence (Kassin, 1997). Inspired by the tragic tales from prison told in Scheck, Neufeld, and Dwyer's (2000) Actual Innocence, the second objective is to isolate and amplify a surprising signal that has emerged in several recent empirical studies: that innocence may put innocent people at risk during a criminal investigation, often to their own detriment. The third objective is to propose that policies for the reform of interrogation practices and the mandatory videotaping of all interviews and interrogations offer the most effective means of protection.

\section{The Preinterrogation Interview}

Over the years, I have asked numerous police investigators, confident of their training-based skills at interviewing and interrogation, if they were concerned that their persuasive methods of influence might cause innocent people to con- fess. The most common answer, which I have heard repeatedly, is "No, because I do not interrogate innocent people."

To understand this remark, one must know that the highly confrontational process of interrogation is preceded by a neutral, information-gathering interview structured to determine if the suspect is guilty or innocent. Sometimes, this initial judgment is reasonably based on witnesses, informants, or other extrinsic evidence. At other times, it may be based on crime-related schemas or "profiles" about likely perpetrators and motives (Davis \& Follette, 2002) — as in the belief that marital infidelity is probative of a husband's involvement in his wife's murder (Wells, 2003). At still other times, however, such judgments are based on nothing more than a hunch, a clinical impression that investigators form during a preinterrogation interview. For example, Inbau, Reid, Buckley, and Jayne (2001) authors of Criminal Interrogations and Confessions (4th ed.), the manual that underlies the influential Reid technique-advise investigators in the use of various verbal cues (e.g., qualified or rehearsed responses), nonverbal cues (e.g., gaze aversion, frozen posture, slouching), and behavioral attitudes (e.g., anxious, unconcerned, guarded) as indicators of deception. In this way, they claim, investigators can be trained to judge truth and deception at an $85 \%$ level of accuracy (see www.reid.com/service-baiinterview.html) —an average that substantially exceeds human lie detection performance obtained in any of the world's laboratories. ${ }^{1}$ For the person who stands falsely accused, this preliminary judgment becomes a pivotal choice-point, determining whether he or she is interrogated or sent home. Hence, it is important to know how-and how well — that judgment is made.

To illustrate the risk of error at this stage, consider the case of Tom Sawyer, in Florida, where investigators accused him of sexual assault and murder, interrogated him for 16 hours, and extracted a confession. His statement was ultimately suppressed by the judge and the charges were dropped. The reason Sawyer became a prime suspect was that his face flushed and he appeared embarrassed during an initial interview, a reaction interpreted as a sign of deception. Investigators did not know that Sawyer was a recovering alcoholic with a social anxiety disorder that caused him to sweat profusely and blush in evaluative social situations (Leo \& Ofshe, 1998). In another, more recent case, 14-year-old Michael Crowe and his friend Joshua Treadway were induced during lengthy and suggestive interrogations into confessing to the stabbing death of Michael's sister Stephanie. The charges against the boys were later dropped when a drifter lurking in the area that night was found with the victim's blood on his clothing. Why were these boys targeted in the first place? It seems that Crowe became a prime suspect when the detectives

${ }^{1}$ After testing more than 13,000 people from all walks of life, O'Sullivan and Ekman (2004) have thus far identified only 15 "wizards" of lie detection who can consistently achieve at least an $80 \%$ level of accuracy in their judgments. 
assigned to the case believed that he had reacted to his sister's death with inappropriately little emotion (see www.courttv.com/trials/tuite).

Despite popular conceptions, research has failed to support the claim that groups of individuals can attain high-average levels of performance in judgments of truth and deception. Most experiments have shown that people perform at no better than chance level (DePaulo, Stone, \& Lassiter, 1985; Memon, Vrij, \& Bull, 2003; Vrij, 2000; Zuckerman, DePaulo, \& Rosenthal, 1981); that training programs produce, at best, small and inconsistent improvements compared with naive control groups (Bull, 1989; Kassin \& Fong, 1999; Porter, Woodworth, \& Birt, 2000; Vrij, 1994; Zuckerman, Koestner, \& Alton, 1984); and that police investigators, judges, psychiatrists, customs inspectors, polygraph examiners, and others with relevant job experience perform only slightly better than chance, if at all (Bull, 1989; DePaulo, 1994; DePaulo \& Pfeifer, 1986; Ekman \& O’Sullivan, 1991; Garrido, Masip, \& Herrero, 2004; Granhag \& Strömwall, 2004; Koehnken, 1987; Porter et al., 2000).

One might argue that performance in the laboratory is poor because participating investigators are asked to detect truths and lies given in situations with low levels of involvement. Indeed, research shows that low-stake situations can weaken deception cues and make the statements more difficult to judge (DePaulo et al., 2003). However, forensic studies using high-stake lies have thus far produced mixed results, with some suggesting that police can sometimes make these judgments at modestly high levels of accuracy (Mann, Vrij, \& Bull, 2004) and others suggesting that they are not necessarily more accurate (Vrij \& Mann, 2001). One might also argue that professionals would be more accurate if they were to conduct the interviews personally rather than merely observe the sessions. But research does not support this notion. Buller, Strzyzewski, and Hunsaker (1991) had observers watch videotaped conversations between participants, one of whom was instructed to lie or tell the truth. The observers were more accurate in assessments of the target than were those engaged in the conversation. Similarly, Hartwig, Granhag, Strömwall, and Vrij (2004) had some police officers interview college students who were guilty or innocent of committing a mock crime while other officers observed videotapes of the interviews. Overall levels of accuracy did not exceed chance-level performance, and those who conducted the interviews were not more accurate than those who merely observed them.

A series of studies examined whether special training increases judgment accuracy in a forensic context. In one study, college students were trained in the detection of truth and deception before obtaining their judgments of mock suspects (Kassin \& Fong, 1999). The study was unique in two ways. First, some participants but not others were randomly assigned to receive training in the Reid technique. Second, judgments were made for a set of videotapes depicting brief interviews and denials by individuals who were truly guilty or innocent of committing one of four mock crimes. As in studies in nonforensic settings, observers were generally unable to differentiate between suspects better than would be expected by chance. In fact, those who underwent training were less accurate than naive controls - though they were more confident and cited more reasons as a basis for these judgments. Closer inspection of the data indicated that the training procedure itself produced a response bias toward guilt. This experiment thus suggests that special training in deception detection may lead investigators to make prejudgments of guilt, with confidence, that are frequently in error.

From a practical standpoint, this study was limited by the use of student observers, not experienced detectives, whose training was condensed, not offered as part of professional development. A meta-analysis and a follow-up study were conducted to examine the performance of real, experienced investigators in order to address this limitation (Meissner \& Kassin, 2002). First, signal detection theory was used to examine the research literature and separate discrimination accuracy and response bias. Six studies were identified: four that compared investigators and naive participants and two that manipulated training. Across studies, investigators and trained participants, relative to naive controls, exhibited a proclivity to judge targets as deceptive. Second, the tapes from an earlier study (Kassin \& Fong, 1999) were used to test police samples from the United States and Canada, and investigators-compared with college students-were found to exhibit lower, chance-level accuracy, a response bias toward deception, and significantly higher confidence. Among the investigators, years of experience and special training both correlated significantly with response bias but not with accuracy. This latter result is now supported by other types of research. Using a standardized self-report instrument, for example, Masip, Alonso, Garrido, and Anton (in press) found that police officers harbor a "generalized communicative suspicion" compared with laypersons.

Lying does leave certain behavioral traces (DePaulo et al., 2003), people can often discriminate truths and lies via indirect detection deception measures (Vrij, Edward, \& Bull, 2001), and some individuals are intuitively better at detecting deception than others (Ekman, O'Sullivan, \& Frank, 1999), so it remains a reasonable goal to seek future improvements in training to make police better interviewers (Bull \& Milne, 2004) and lie detectors (Vrij, 2004). At present, however, the decision to interrogate innocent people because of their interview behavior is based on judgments confidently made but biased and frequently in error. Expressing a particularly cynical view, one detective said, "You can tell if a suspect is lying by whether he is moving his lips" (Leo, 1996a, p. 23).

\section{The Miranda Waiver}

Innocence does not protect a suspect from interview-based judgments of deception. For those who "fail" (i.e., who are judged as being deceptive), the questioning transitions into a highly confrontational interrogation characterized by the use of social influence tactics to be described later. In place, however, is one procedural safeguard designed to protect the accused from this process. In the landmark case of 
Miranda v. Arizona (1966), the U.S. Supreme Court ruled that police must inform all suspects in custody of their Constitutional rights to silence and to counsel-and suspects must voluntarily, knowingly, and intelligently waive these rights. A number of subsequent rulings carved out exceptions to this rule and limited the consequences for noncompliance (Harris v. New York, 1971; Michigan v. Harvey, 1990; New York v. Quarles, 1984), developments that have led some legal scholars to question the extent to which police are free to disregard Miranda (Clymer, 2002; White, 2003). In two important recent decisions, the Supreme Court upheld the basic warning-and-waiver requirement (Dickerson v. United States, 2000)-for example, refusing to accept confessions given after a warning that was tactically delayed to produce an earlier inadmissible statement (Missouri v. Seibert, 2004). Practically speaking, however, the requirement may have little effect. Empirical research shows that many juvenile suspects do not fully comprehend or know how to apply these rights (Grisso, 1981, 1998; Oberlander \& Goldstein, 2001), nor do adults with mental retardation or others who are naive about the criminal justice system (Cloud, Shepherd, Barkoff, \& Shur, 2002; Fulero \& Everington, 1995, 2004).

Given the inherently coercive nature of a police interrogation, one would surmise that a vast majority of suspects would exercise their constitutional rights to silence and to counsel and avoid the perils of interrogation. However, research suggests the opposite tendency. From naturalistic observations of live and videotaped interrogations, Leo (1996a) found that roughly four out of five suspects waive their rights and submit to questioning (see Leo \& White, 1999). Archival studies in Great Britain reveal a similar, if not higher, waiver rate (Baldwin, 1993; Moston, Stephenson, \& Williamson, 1993; Softley, 1980). One possible explanation for this tendency is that police have learned how to obtain waivers. For example, Leo (1996b) observed that detectives often overcome Miranda by making small talk and strategically establishing rapport with the suspect, a social influence tactic that increases compliance with later requests (Nawrat, 2001). Police may also offer sympathy and an apparent ally and refer to the process as a mere formality, thus increasing perceived benefits relative to costs (Leo, 1996a). In some jurisdictions, police are specifically trained to get suspects to talk "outside Miranda"-even after they invoke their rights. Statements taken in this manner cannot be used at trial in the state's case in chief. But such "off the record" disclosures may be used both to generate other admissible evidence and to impeach the defendant at trial if he or she chooses to testify (Philipsborn, 2001; Weisselberg, 2001).

A second possible explanation for this tendency of suspects to waive their rights is suggested by individual differences among actual suspects. Replicating a result previously observed in Great Britain, Leo (1996b) found that individuals who have no prior felony record are more likely to waive their rights than are those with a history of criminal justice "experience." In light of known recidivism rates in criminal behavior and the corresponding base rate assumption that people without a criminal past are less likely to commit crimes, this demographic difference suggests the hypothesis that innocent people in particular are at risk to waive their rights. This hypothesis was tested in a controlled laboratory setting (Kassin \& Norwick, 2004). Seventy-two participants who were guilty or innocent of a mock theft of $\$ 100$ were apprehended for investigation. Motivated to avoid further commitments of time without compensation, they were confronted by a neutral, sympathetic, or hostile male "detective" who sought a waiver of their Miranda rights. Overall, 58\% of suspects waived their rights. Although the detective's approach had no effect, participants who were innocent were substantially more likely to sign a waiver than those who were guilty-by a margin of $81 \%$ to $36 \%$. This decision-making tendency emerged in all conditions and was so strong that $67 \%$ of innocents signed the waiver even when paired with a hostile, closed-minded detective who barked, "I know you did this and I do not want to hear any lies!" (see Table 1).

To understand these waiver rates, we asked participants afterward to explain the reasons for their decisions (Kassin \& Norwick, 2004). Overall, 92\% of the guilty suspects who waived the rights stated strategic self-presentation reasons for that decision (e.g., "If I didn't, he'd think I was guilty"; "I would've looked suspicious if I chose not to talk"). Although some innocent suspects gave similar strategic explanations, $72 \%$ also or solely explained that they waived their rights precisely because they were innocent (e.g., "I did nothing wrong," "I did not have anything to hide"). It appears that people have a naive faith in the power of their own innocence to set them free.

The phenomenology of innocence may be rooted in a generalized and perhaps motivated belief in a just world in which human beings get what they deserve and deserve what they get (Lerner, 1980). It may also stem from of an "illusion of transparency," a tendency for people to overestimate the extent to which their true thoughts, emotions, and other inner states can be seen by others (Gilovich, Savitsky, \& Medvec, 1998; Miller \& McFarland, 1987). Either way, this study, along with naturalistic observations

\section{Table 1}

Percentage of Participants Who Agreed to Waive Their Rights as a Function of Guilt or Innocence and Interview Condition

\begin{tabular}{lcccc}
\hline & \multicolumn{4}{c}{ Interrogation condition } \\
\cline { 2 - 5 } Suspect & Neutral & Sympathetic & Hostile & Total \\
\hline Guilty (\%) & 33 & 33 & 42 & 36 \\
Innocent (\%) & 83 & 92 & 67 & 81 \\
Total (\%) & 58 & 63 & 54 & \\
\hline
\end{tabular}

Note. From "Why Suspects Waive Their Miranda Rights: The Power of Innocence," by S. M. Kassin and R. J. Norwick, 2004, Law and Human Behavior, 28, Table 1, p. 215 . Copyright 2004 by Springer Science and Business Media. Reprinted with permission. 
(e.g., Leo, 1996a), suggests that Miranda warnings may not adequately protect the citizens who need it most-those accused of crimes they did not commit. With tragic results, this problem was evident in the classic case of Peter Reilly, an 18-year-old who confessed and internalized guilt for the murder of his mother. Solely on the basis of his confession, Reilly was prosecuted, convicted, and imprisoned until independent evidence revealed that he could not have committed the murder. When asked years later why he did not invoke his Miranda rights, Reilly said, "My state of mind was that I hadn't done anything wrong and I felt that only a criminal really needed an attorney, and this was all going to come out in the wash" (Connery, 1996, p. 93).

This phenomenology may lead innocents to forego other important rights as well. In the context of eyewitness evidence, Gary Wells (personal communication) noted that Louisville police often ask suspects to waive their right to a full lineup, surrounded by foils, in favor of a one-on-one "show-up." Are innocent people more likely to sacrifice the protection afforded by a lineup out of a naive belief that they are invulnerable to misidentification? In a study that tested this hypothesis (Holland, Kassin, \& Wells, 2005), participants engaging in a mock theft were told to steal a package from a public area, toss it into a trash container, and flee to a preset location, where there they were apprehended by a security officer and "processed." Others reported to a different location, engaged in a noncriminal act, and returned, also to be apprehended. All participants were offered a financial inducement to avoid being charged. The officer then revealed that there was an eyewitness present whose general description fit the participant. He said that he had to wait for additional photos to arrive in order to assemble a lineup and offered a one-on-one show-up as an alternative. "In other words, I can show the witness just your photo to see if he or she identifies you." Among guilty participants, only $47 \%$ waived the lineup; among the innocents, $100 \%$ waived the lineup. In this latter group, two thirds cited their innocence as a reason not to fear the one-on-one situation.

\section{The Interrogation}

The tendency for investigators to make false-positive errors of deception during preinterrogation interviews and the tendency for innocent people to waive their rights combine to increase the likelihood that innocent suspects are interrogated by detectives who presume guilt, often with certainty. Yet Inbau et al. (2001) advise that "the successful interrogator must possess a great deal of inner confidence in his ability to detect truth or deception, elicit confessions from the guilty, and stand behind decisions of truthfulness" (p. 78).

The inherent danger in this two-step approach should be self-evident. By definition, it means that interrogation is a guilt-presumptive process, a theory-driven social interaction led by an authority figure who holds a strong a priori belief about the target and who measures success by his or her ability to extract a confession. It is possible that police who commit themselves to this course of action are, at times, not merely blinded by their initial beliefs but moti- vated to reinforce them (e.g., by a desire for closure, to help secure a conviction). For innocent people initially misjudged, one would hope that investigators would remain open-minded and periodically reevaluate their beliefs. However, a warehouse of psychology research suggests that once people form an impression, they unwittingly seek, interpret, and create behavioral data that verify it. This last phenomenon-variously referred to by the terms selffulfilling prophecy, interpersonal expectancy effect, and behavioral confirmation bias - was demonstrated by Rosenthal and Jacobson (1968) in their classic field study of teacher expectancy effects, with similar results later obtained in military, business, and other organizational settings (McNatt, 2000). Similar results have also been obtained in the laboratory (e.g., Snyder \& Swann, 1978). Indeed, experiments have shown that behavioral confirmation results from a three-step chain of events, by which a perceiver forms a belief about a target person; the perceiver behaves toward the target in a manner that conforms to that belief; and the target responds in turn, often behaving in ways that support the perceiver's belief (Darley \& Fazio, 1980; Nickerson, 1998; Snyder, 1992; Snyder \& Stukas, 1999).

Can the presumption of guilt influence the way police conduct interrogations, perhaps leading them to adopt a questioning style that is highly aggressive? If so, can this approach lead innocent people to become anxious and defensive, thereby providing pseudodiagnostic support for the presumption of guilt? Demonstrating that interrogators can condition the behavior of suspects through an automatic process of social mimicry (see Chartrand \& Bargh, 1999), Akehurst and Vrij (1999) found that increased movement among police officers triggered movement among interviewees-fidgeting behavior that is seen by others as suspicious.

The hypothesis that the presumption of guilt shapes the conduct of student interrogators, their suspects, and ultimately the judgments made by neutral observers was specifically tested in a two-phased study (Kassin, Goldstein, \& Savitsky, 2003). In Phase 1, suspects stole \$100 as part of a mock theft or engaged in a related but innocent act, after which they were interviewed via headphones from a remote location. Others, serving as investigators, were led to believe that most suspects were either guilty or innocent. The sessions were audiotaped and followed by postinterrogation questionnaires. In Phase 2, conditionblind observers listened to the taped interviews, judged the suspect as guilty or innocent, and rated their impressions of both sets of participants.

Overall, investigators who were led to expect guilt rather than innocence asked more guilt-presumptive questions, used more techniques, exerted more pressure to get a confession, and made innocent suspects sound more anxious and defensive to observers. They were also more likely to see suspects in incriminating terms, exhibiting a $23 \%$ increase in postinterrogation judgments of guilt. Observers who later listened to the tapes also perceived suspects in the guilty expectations condition as more defensive and as somewhat more likely to have committed the mock crime. The presumption of guilt, which underlies interro- 
gation, thus set into motion a process of behavioral confirmation, shaping the interrogator's behavior, the suspect's behavior, and ultimately the judgments of neutral observers. What we did not predict was the paradoxical and disturbing effect that actual innocence had on the perceiver-target interaction (Kassin et al., 2003). According to observers, innocent suspects told the more plausible denial stories. Yet these suspects brought out the worst in the guilt-presumptive interrogators. As rated by all participants, the most pressure-filled sessions occurred in the one cell of the $2 \times 2$ factorial design that paired interrogators who presumed guilt with suspects who were innocent (see Figure 1). Apparently, interrogators who approached the task with a guilty base-rate expectation did not reevaluate this belief even when paired with innocent people who issued plausible denials. Instead, they appeared to see these denials as proof of a guilty person's resistance-and redoubled their efforts to elicit a confession.

It is clear that police interrogation is a generally guiltpresumptive process that can set into motion a range of cognitive and behavioral confirmation biases (Meissner \& Kassin, 2004). It is also important, however, to know whether the specific techniques that are employed lead people to confess to crimes they did not commit. In contrast to past practices that relied on physical "third degree" tactics, modern American police interrogations are presented in a manner that is professional and psychologically oriented (for a historical perspective, see Leo, 2004). Approaches vary within criminal justice, military, and intelli-

\section{Figure 1}

Observer Ratings of How Hard the Interrogators Tried to Get Confessions as a Function of Interrogators' Expectations and Suspects' Guilt or Innocence

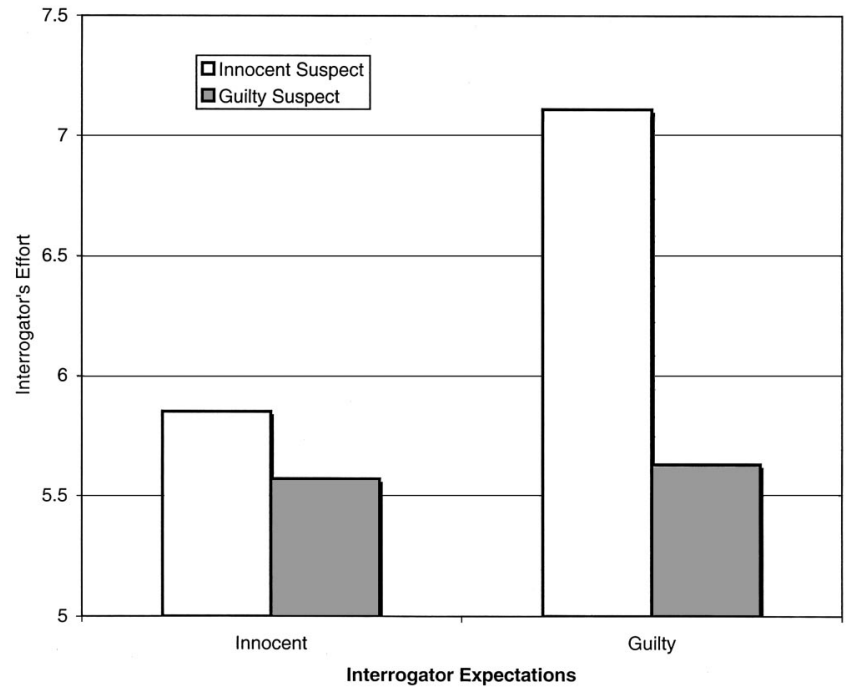

Note. Adapted from "Behavioral Confirmation in the Interrogation Room: On the Dangers of Presuming Guilt," by S. M. Kassin, C. J. Goldstein, and K. Savitsky, 2003, Law and Human Behavior, 27, Figure 2, p. 198. Copyright 2003 by Springer Science and Business Media. Adapted with permission. gence settings, and numerous training manuals are currently available (e.g., Gordon \& Fleisher, 2002; Walters, 2003). As noted earlier, the most influential is Inbau et al.'s (2001) Criminal Interrogation and Confessions, first published in 1962, cited by the U.S. Supreme Court in Miranda v. Arizona (1966), and now in its fourth edition.

In the so-called Reid technique, interrogators are advised to dress in civilian clothing and isolate the suspect in a small, bare, soundproof room. Against this physical backdrop, they describe an operational nine-step process that begins when an interrogator confronts the suspect with assertions of guilt (Step 1), then develops "themes" that psychologically justify or excuse the crime (Step 2), interrupts all efforts at denial (Step 3), overcomes the suspect's factual, moral, and emotional objections (Step 4), ensures that the passive suspect does not withdraw (Step 5), shows sympathy and understanding and urges the suspect to cooperate (Step 6), offers a face-saving alternative construal of the alleged guilty act (Step 7), gets the suspect to recount the details of his or her crime (Step 8), and converts the latter statement into a full written confession (Step 9). Conceptually, this procedure is designed to get suspects to incriminate themselves by increasing the anxiety associated with denial and minimizing the perceived consequences of confession.

As a historical matter, criminal justice statistics bear witness to the effectiveness of this approach at eliciting confessions, and so does a long tradition of psychological theory and research. It is now axiomatic that people are responsive to reinforcement and subject to the principles of conditioning and that behavior is influenced by perceptions of immediate and delayed consequences. Of distal relevance to a psychological analysis of interrogation are thousands of operant studies of appetitive, avoidance, and escape learning, as well as human decision making in the behavioral economics paradigm - as in studies on the discounting of rewards and costs over time. Looking through a behavioral lens, one is struck by the ways in which police investigators can shape suspects to confess as if they were rats in a Skinner box. At the same time, social psychologists note that people are inherently social beings and are vulnerable to influence from change agents who effectively use sequential request strategies, as in the foot-in-the-door effect, to elicit compliance (Cialdini, 2001) and a gradual escalation of commands to elicit self- and other-defeating acts of conformity and obedience (Milgram, 1974). For example, Latane's (1981) social impact theory would predict high levels of influence by police interrogators-who bring power, proximity, and number to bear on the exchange (for social psychological perspectives, see Bem, 1966; Davis \& O’Donohue, 2003; Zimbardo, 1967).

In light of research showing that police are prone to misjudge truthful suspects as deceptive and that innocent people tend to waive their Miranda rights, it is important to know whether the techniques of interrogation are "surgically precise" in their effects, drawing confessions from those who are guilty but not from those who are innocent. As no one knows the frequency of false confessions or has devised an adequate method of calculating it, there is 
perennial debate over the incidence rate and whether it can be derived (e.g., Cassell, 1996, 1999; Leo \& Ofshe, 1998, 2001). Notwithstanding this numbers controversy, Kassin and Wrightsman (1985) introduced a taxonomy that distinguished among three types of false confessions. Voluntary false confessions are self-incriminating statements offered without external pressure. Coerced-compliant false confessions are those in which a suspect confesses to escape an aversive interrogation, avoid an explicit or implied threat, or gain a promised or implied reward. This type of confession is a mere act of public compliance by a suspect who knows that he or she is truly innocent (e.g., the Central Park jogger case, where each of the boys said he had confessed expecting to go home). Finally, coerced-internalized false confessions are those in which an innocent person-tired, confused, and subjected to highly suggestive procedurescomes to believe that he or she committed the crime, sometimes forming a false memory in the process. This classification scheme has provided a useful framework for the study of false confessions and has been used, critiqued, extended, and refined by others (Conti, 1999; Gudjonsson, 1992, 2003; Inbau et al., 2001; Kassin, 1997; Lassiter, 2004; McCann, 1998; Ofshe \& Leo, 1997; Wrightsman \& Kassin, 1993).

As noted earlier, a disturbing number of cases have surfaced in which defendants who had confessed were convicted and sometimes sentenced to death, only later to be exonerated by DNA or other irrefutable evidence. It is now clear that certain situational factors increase influence and the risk of false confession. Consider the Reid technique, the nine steps of which are essentially reducible to three processes:

- isolation, often in a special interrogation room, which increases anxiety and the incentive to escape;

- confrontation, in which the suspect is accused of the crime, presented with evidence, real or manufactured, and blocked from denial;

- minimization, in which the crime is morally justified by a sympathetic interrogator, leading suspects to see confession as a possible means of "escape" (see Kassin, 1997). ${ }^{2}$

To begin with, isolation heightens the stress of custodial interrogation, especially after extended periods of time, thus increasing a suspect's motive to escape. Controlled laboratory experiments show that fatigue and sleep deprivation, which accompany prolonged periods of isolation, can heighten susceptibility to influence and impair complex decision-making abilities (Blagrove, 1996; Harrison \& Horne, 2000). Thus, it comes as little surprise that whereas most police interrogations last for less than 2 hours (Leo, 1996a), and whereas 3 or 4 hours are usually sufficient (Inbau et al., 2001), a recent analysis of proven false confession cases in which interrogation times were available revealed that 34\% lasted 6-12 hours, 39\% lasted 12-24 hours, and the mean was 16.3 hours (Drizin \& Leo, 2004). In the Central Park jogger case, the five boys had been in custody and under some constancy of interrogation for 14-30 hours when they confessed (New York v. Wise et al., 2002).

Once suspects are isolated, interrogators confront them with bold assertions of guilt - a process that encompasses methods of overcoming denials and may even involve the presentation of allegedly incontrovertible evidence (e.g., a fingerprint, blood or hair sample, eyewitness identification, or failed polygraph)_regardless of whether such evidence exists. In a recent exoneration case described earlier, for example, 14-year-old Michael Crowe falsely confessed to the stabbing death of his sister Stephanie. Michael vehemently denied the charge at first but then capitulated after being told that his hair was found in Stephanie's grasp, that her blood was in his bedroom, that all means of entry to the house were locked, and that he had failed a lie detector test-all claims that were untrue (Drizin \& Colgan, 2004). In the United States, this form of trickery is permissible (Frazier v. Cupp, 1969), recommended under certain circumstances (Inbau et al., 2001), and frequently used (Leo, 1996a). Yet as the decision to confess is influenced by a suspect's expectations about the relative consequences of confession and denial, research shows that people capitulate when they believe that the police have strong evidence against them (Moston, Stephenson, \& Williamson, 1992). Moreover, laboratory experiments have shown that false evidence increases the risk that innocent people confess to acts they did not commit and internalize blame for outcomes they did not produce.

In the first such study, Kassin and Kiechel (1996) had college students type letters on a keyboard in what was supposed to be a reaction time study. At one point, participants were accused of causing the experimenter's computer to crash by pressing a key they were instructed to avoid-at which point they were asked to sign a confession. All participants were truly innocent and all initially denied the charge. In some sessions, a confederate told the experimenter that she witnessed the participant hit the forbidden key; in others she said she did not witness what happened. This false evidence significantly increased the number of students who signed a written confession, from $48 \%$ to $94 \%$ (as measured moments later, the presentation of false evidence also increased the number of participants who believed they were truly responsible for this outcome they did not produce). Follow-up studies have replicated this effect, even when the confession was said to bear a financial consequence (Horselenberg, Merckelbach, \& Josephs, 2003), and particularly among stress-induced males (Forrest, Wadkins, \& Miller, 2002) and juveniles-who are more vulnerable to the effect than adults (Redlich \& Good-

${ }^{2}$ Other tactics are often used that are not strictly derived from the Reid technique-such as exploiting a suspect's sense of guilt over unrelated or collateral matters; appealing to God and religion; suggesting to the suspect that he or she lacks a memory of the crime because of a blackout, dissociation, or repression; and urging the suspect to "imagine" how the crime was committed. Along with presenting false evidence, these latter tactics can trick innocent people into believing in their own culpability (see Gudjonsson, 2003; Henkel \& Coffman, 2004; Kassin, 1997; Kopelman, 1999). 
man, 2003). Indeed, the problem of false confessions in wrongful convictions is most acute among juveniles and persons with mental illness (Drizin \& Leo, 2004; Redlich, 2004; Redlich, Silverman, Chen, \& Steiner, 2004).

For suspects thrust into a state of despair by the tactics of confrontation, the next step is to minimize the crime by providing moral justification or face-saving excuses, making confession seem like an expedient means of escape. Interrogators thus suggest that the crime was spontaneous, accidental, provoked, drug-induced, or otherwise justified by extenuating circumstances. In the Central Park jogger case, every boy gave a false confession that placed his cohorts at center stage and minimized his own involvement (e.g., Kharey Wise said he had felt pressured by peers). Each said afterward that he thought he would go home.

Over the years, most courts have rejected as involuntary confessions taken by direct threats or promises, acknowledging the risk to innocent people. But the courts have not similarly excluded confessions drawn from threats and promises that were merely implied by minimization tactics (White, 2003). Research shows that such tactics lead readers of an interrogation transcript to infer by pragmatic implication that leniency in sentencing will follow from confession, even in the absence of an explicit promise (Kassin \& McNall, 1991). Although more work is needed to compare different forms of minimization (e.g., provocation vs. accident scripts), it is now clear that this cornerstone tactic of the Reid technique circumvents the exclusion of promise-elicited confessions by enabling police to communicate leniency "under the radar."

In a study designed to assess the behavioral effects of minimization on the elicitation of true and false confessions, Russano, Meissner, Narchet, and Kassin (in press) devised a laboratory paradigm in which participants were paired with a confederate for a problem-solving study and instructed to work alone on some trials and jointly on others. In a guilty condition, the confederate sought help on an individual problem, inducing a violation of the experimental prohibition; in the innocent condition, the confederate did not make this request to induce the crime. The experimenter soon "discovered" the similarity in their solutions, separated the participant and confederate, and accused the participant of cheating. The experimenter tried to get the participant to sign an admission by promising leniency (research credit in exchange for a return session without penalty), making minimizing remarks ("I'm sure you didn't realize what a big deal it was"), using both tactics, or using no tactics.

Overall, the rate of admission was higher among guilty participants than innocent, when leniency was promised than when it was not, and when minimization was used than when it was not. As for the effect of minimization on the all-important diagnosticity ratio (i.e., of true admissions to false), diagnosticity was highest in the no-tactics cell (where $46 \%$ of guilty suspects confessed vs. only $6 \%$ of innocents), and minimization-just like an explicit offer of leniency - reduced diagnosticity by increasing not only the rate of true confessions but false confessions as well $(81 \%$ vs. $18 \%$ ) (see Table 2). In short, minimization provides a
Table 2

Percentage of True and False Confessions and Resulting Diagnosticity Ratios by Interrogation Condition

\begin{tabular}{lccc}
\hline Condition & $\begin{array}{c}\text { True } \\
\text { confessions } \\
(\%)\end{array}$ & $\begin{array}{c}\text { False } \\
\text { confessions } \\
(\%)\end{array}$ & $\begin{array}{c}\text { Diagnosticity } \\
\text { ratio }\end{array}$ \\
\hline No tactic & 46 & 6 & 7.67 \\
Leniency offer & 72 & 14 & 5.14 \\
Minimization & 81 & 18 & 4.50 \\
Both & 87 & 43 & 2.02 \\
\hline
\end{tabular}

Note. From "Investigating True and False Confessions Within a Novel Experimental Paradigm," by M. B. Russano, C. A. Meissner, F. M. Narchet, and S. M. Kassin (in press), Psychological Science, Table 2. Copyright 2005 by Blackwell Publishing Ltd. Reprinted with permission.

loophole in the rules of evidence by serving as the implicit functional equivalent to a promise of leniency (which typically renders a confession inadmissible). The net result is to put innocents at risk to make false confessions.

\section{The Consequences of Confession: Where Is the Safety Net?}

One might argue that because human beings are imperfect, innocent people will sometimes be targeted for interrogation, presumed guilty, and subjected to excessively persuasive tactics, and that many will naively and in opposition to their own self-interest waive their rights. However, one might also argue that these problems are tolerable to the extent that the resulting false confessions are detected by authorities and corrected. Essential to this presumed safeguard, then, is a commonsense assumption, built on blind faith, that "I'd know a false confession if I saw one."

Research on the impact of confessions on jurors and others in the criminal justice system is not encouraging on this front. Mock jury studies have shown that confessions have more impact than eyewitness and character testimony, other potent forms of human evidence (Kassin \& Neumann, 1997), and that people do not fully discount confessions even when it is logically and legally appropriate to do so (Kassin \& Sukel, 1997; Kassin \& Wrightsman, 1980). Confessions also tend to overwhelm alibis and other forms of exculpatory evidence, resulting in a chain of adverse legal consequences-from arrest through prosecution, conviction, and incarceration (Drizin \& Leo, 2004; Leo \& Ofshe, 1998). Often prosecutors refuse to concede innocence even after DNA tests unequivocally absolve the wrongfully convicted confessor. For example, Bruce Godschalk was exonerated of two rape convictions by DNA after 15 years in prison when tests independently conducted by laboratories for the state and defendant indicated that he was not the rapist. Yet the district attorney whose office had convicted Godschalk surmised that the DNA tests were flawed and refused, at first, to release him from prison. When questioned about the decision, this district attorney 
said, "I have no scientific basis. I know because I trust my detective and his tape-recorded confession. Therefore the results must be flawed until someone proves to me otherwise" (Rimer, 2002).

Clearly, confession evidence is powerful, and its impact during and after trial is hard to overcome. To safeguard against wrongful convictions, therefore, it is vitally important that confessions be accurately assessed by police and prosecutors prior to the onset of court proceedings. But can people really distinguish between true and false confessions? Recent research has yielded sobering results. In one study, Lassiter, Clark, Daniels, and Soinski (2004) modified the computer crash paradigm (Kassin \& Kiechel, 1996) mentioned earlier to elicit true and false oral confessions in the laboratory, confessions that were videotaped for others to judge. Overall, student observers were not better than chance at differentiating the confessions of guilty and innocent participants (see Lassiter \& Geers, 2004).

Perhaps laypeople cannot differentiate among laboratory confessions, but can police distinguish between true and false confessions to actual crimes? In a two-part study (Kassin, Meissner, \& Norwick, in press), male prison inmates were recruited to take part in a pair of videotaped interviews. Each inmate was instructed to give a full confession to the crime for which he was incarcerated, a narrative that was followed by a standardized list of questions. In a second interview, each inmate received a skeletal, one-sentence description of a crime committed by another inmate and was asked to concoct a false confession. Using this yoked design, one inmate's true confession served as the basis of the second inmate's false confession, and so on. In this way, a videotape was created that depicted 10 different inmates, each giving a true or false confession to one of five crimes: aggravated assault, armed robbery, burglary, breaking and entering, and automobile theft. College students and police investigators judged these statements, and the results paralleled those found for judgments of denials. Neither group exhibited high levels of accuracy, though the police were more confident in their performance. A signal detection analysis further revealed that police did not differ from students in their hit rate but committed significantly more false alarms. This response bias was most evident among those with extensive law enforcement experience and those specially trained in interviewing and interrogation.

On the broad question of whether innocence is detectable, there are three reasons for pessimism. First, the common sense of attribution leads people to expect self-serving behavior in others - and hence, to trust confessions. Across a wide range of settings, social psychologists have found that people commit what Ross (1977) called the "fundamental attribution error"-making dispositional attributions for a person's actions, taking behavior at face value, and underestimating the role of situational factors (see Gilbert \& Malone, 1995; Jones, 1990). Second, as noted earlier, people are generally not adept at deception detection, even in judging denials (Kassin \& Fong, 1999; Meissner \& Kassin, 2002) and statements unrelated to crime commission (DePaulo et al., 1985; Memon et al., 2003). Third, and most specific, police-induced false confessions often contain content cues that people associate with truth telling-such as vivid sensory details of the crime, scene, and victim, details that can become known to an innocent suspect through leading questions, overheard conversations, photographs, visits to the crime scene, and other secondhand sources. To further obfuscate matters, many confessions, true and false, are textured with "elective" remarks in which suspects describe not just what they allegedly did, and how, but why-as they self-report on revenge, jealousy, desperation, peer pressure, and other prototypical motives. Many false confessions also contain apologies and expressions of remorse (Central Park jogger defendant Kharey Wise promised in his false confession that he would not rape again). To naive observers, the statements appear voluntary, accurate, and the product of personal experience. It is all too easy, however, to mistake illusion for reality and not to realize that a police-induced confession is like a Hollywood drama: scripted by the interrogator's theory of the case, shaped through questioning and rehearsal, directed by the questioner, and enacted by the suspect (Kassin, 2004a).

In the absence of an adequate means of protection in law or in practice, psychologists have a great deal to offer, at times intervening as confession experts in court. Gudjonsson (2002) noted that psychologists - through their research and expert testimony-have had a substantial impact in recent years on law, police practice, trial verdicts, and appellate decisions in Great Britain. In the United States, psychological experts have testified in large numbers of criminal and civil trials, but they have been excluded in other trials. Although case law continues to evolve in state and federal courts, it appears that expert testimony is often, though not always, permitted for the purpose of informing a jury about relevant general principles (e.g., psychopathology, social influence, and decision making) but not for the purpose of rendering an opinion on a particular confession (United States v. Hall, 1997; for a review, see Fulero, 2004). Such testimony is now amply supported not only by anecdotes and case studies of wrongful convictions but by a long history of basic psychology and a growing forensic research literature, as summarized in several recently published books (e.g., Gudjonsson, 2003; Lassiter, 2004; Memon et al., 2003).

\section{Conclusions and Implications}

The Central Park jogger case-like other wrongful convictions of recent years- has revealed a sequence of problems: (a) Innocent people are often targeted for interrogation, not protected, on the basis of erroneous interviewbased deception judgments; (b) innocents naively, and often to their own detriment, waive their rights to silence and to counsel; (c) innocents unwittingly trigger aggressive interrogations, which makes them appear anxious and defensive and exacerbates erroneous judgments of guilt; (d) innocents can be induced to confess to crimes they did not commit by deceptive, psychologically oriented methods of interrogation; and (e) it is difficult for police, attorneys, 
judges, and juries to recognize a false confession when they see one. These findings, summarized in Table 3, suggest that there is not sufficient protection within the criminal justice system. They also suggest the ironic hypothesis that beginning in the early stages of a police investigation, innocence may put innocents at risk.

This paradoxical effect may reside in part in the phenomenology of innocence, which leads innocent people to make bad decisions in their own behalf. This mental state leads those who stand falsely accused to believe that truth and justice will prevail. To be sure, innocent suspects, like their guilty counterparts, are motivated in part by strategic self-presentation concerns. Reflecting a fundamental belief in a just world and in the transparency of their own blameless status, however, those who stand falsely accused also have faith that their innocence will become self-evident to others. As a result, they cooperate with police, often not realizing that they are suspects, not witnesses; they waive their rights to silence, counsel, and a lineup; they agree to take lie-detector tests; they vehemently protest their innocence, unwittingly triggering aggressive interrogation behavior; and they succumb to pressures to confess when isolated, trapped by false evidence, and offered hope via minimization and the leniency it implies. Yet without independent exculpatory evidence, their innocence is not easily detected by others.

In a case that illustrates how the phenomenology of innocence can wreak havoc on a suspect's decision making, a man who was ultimately acquitted by a jury had confessed, after 19 hours of interrogation, to his wife's murder when police said that there was blood in his car that would be sent to a laboratory for DNA testing (Missouri v. Johnson, 2001). Knowing that the blood could not be his wife's, this defendant explained later that he confessed

\section{Table 3}

Five Ways in Which Innocence Can Put Innocents at Risk

1. With confidence, police investigators commit falsepositive errors and presume innocent suspects guilty.

2. Naively believing that truth and justice will prevail, innocent suspects waive their rights to silence and to counsel.

3. Despite or because of their plausible and vigorous denials, innocent suspects trigger highly confrontational interrogations.

4. Certain interrogation techniques (e.g., isolation, false evidence, minimization) increase the risk of a false confession.

5. In contrast to the assumption that "I'd know a false confession if I saw one," police overbelieve the confessions of innocent people. because he was exhausted and knew that the test results would show his innocence. It is permissible and common for police to bluff about having DNA testable samples on the assumption that their suspects, whom they presume guilty, will realize the futility of denial and capitulate. To the innocent but beleaguered person, however, who is ignorant about the use of this tactic, the "threat" of DNA may well be construed as a promise of future exonerationmaking it easier to confess.

The foregoing problems should prompt discussion of possible reforms on two levels. First, a science of interrogation should aim to increase the reliability of statements elicited in the interrogation room by finding ways to reduce the number of innocent confessions without significantly inhibiting the rate at which criminals confess. Second, because some degree of error is inevitable in imperfect human systems, other reforms should be designed to assist police, prosecutors, judges, and juries - the key decision makers whose task it is to assess these statements.

\section{Proposals for Reforming the Practices of Interrogation}

One would hope that recent developments and research would inspire a collaborative effort among law enforcement professionals, district attorneys, defense lawyers, judges, social scientists, and policymakers to scrutinize the methods of interrogation that put innocent people at risk. Contextual factors may shift our relative tolerance for false-positive and false-negative errors (e.g., one could argue that the fundamental value, rooted in Blackstone's [1765-1766] Commentaries on the Laws of England, that it is better to acquit 10 guilty people than to convict one who is innocent, may have to be suspended in the interrogation of prospective terrorists who pose an imminent threat). All parties would agree, however, that the surgical objective is to secure confessions from suspects who are guilty but not from those, misjudged, who are innocent. Hence, the process of interrogation should be structured to produce outcomes that are diagnostic of guilt and innocence, as measured by the observed ratio of true to false confessions. Yet except for physical brutality or deprivation, threats of harm or punishment, promises of leniency or immunity, and flagrant violations of Miranda, no objective criteria or limits are imposed. Instead, American courts historically have taken a "totality of the circumstances" approach to voluntariness and admissibility, as articulated in Culombe v. Connecticut (1961), where Justice Frankfurter declared that "there is no simple litmus-paper test" (p. 601). In light of mounting numbers of documented false confessions, many appearing in the database of recent DNA exonerations, as well as recent theory and research, perhaps it is time to revisit this previously eschewed concept of a litmus test.

Three factors in particular should be scrutinized. One concerns custody and interrogation time. Although likely moderated by the suspect's age, the time of day or night, and other circumstances, excessive time is invariably accompanied by stress, fatigue, feelings of helplessness, and a deprivation of sleep, food, social support, and other need 
states. As described earlier, the length of interrogation far exceeds the norm in cases containing proven false confessions. As such, guidelines should be set, as in England, with regard to the amount of continuous time a suspect can be detained and questioned and still produce a statement deemed voluntary.

A second problem concerns the presentation of false evidence, which often takes the egregious form of outright lying to suspects-for example, about an eyewitness identification that was not made; fingerprints, hair, or blood of theirs that was not found; or a polygraph test they did not fail. Because police are more likely in nature to have proof against perpetrators than innocents, the practice of confronting suspects with real evidence, or even just their own inconsistent statements, is a necessary tool that should increase the diagnosticity of the statements ultimately elicited. To the extent that police misrepresent the evidence, however, both guilty and innocent suspects become similarly trapped, reducing diagnosticity. In Frazier v. Cupp (1969), the U.S. Supreme Court considered a case in which police told the defendant that his alibi had confessed, which was not true, and it tacitly sanctioned this deceptionseeing it as relevant to voluntariness but not disqualifying. Since that time the Court has repeatedly declined to reconsider the issue (Magid, 2001). In light of studies showing that the presentation of false evidence draws confessions from the innocent and the numerous false confession cases in which this tactic was implicated, the Court should revisit the wisdom of its prior ruling and declare "Thou shalt not lie.",3

A third risk factor concerns the use of minimization. Over the years, American courts have ruled that confessions lack voluntariness when extracted by direct threats or promises of legal consequences, which can cause innocent people to confess. But they have not similarly excluded confessions drawn from threats and promises that were merely implied-as when police suggest to a suspect that the conduct in question was provoked, an accident, or otherwise morally justified (White, 2003). Research shows that minimization tactics can lead people to infer leniency in sentencing upon confession (Kassin \& McNall, 1991) and that they significantly reduce diagnosticity by increasing false confessions (Russano et al., in press). Although more work is needed to assess different types of minimization (e.g., provocation vs. accident scripts), it appears that this tactic as practiced may circumvent the exclusion in principle of promise-elicited confessions by enabling police to communicate leniency by pragmatic implication.

\section{Videotaping Interrogations: A Policy Whose Time Has Come}

Whatever techniques are used in the interrogation room, one could argue that, voluntarily or under pressure, people will still at times confess to crimes they did not commit. For human decision makers to accurately assess these confessions in order to determine whether to charge, prosecute, convict, and possibly execute the defendant, they should have access to a videotape recording of the entire interview and interrogation. In Great Britain, the Police and Criminal
Evidence Act of 1984 (Home Office, 1985) mandated that all sessions be taped in their entirety. In the United States, only four states-Minnesota, Alaska, Illinois, and Mainepresently have mandatory videotaping requirements, though the practice is common on a voluntary basis in many jurisdictions. ${ }^{4}$ Indeed, studies have shown many police and sheriff's departments routinely videotape interrogations - and that the vast majority of them favor the practice and find it useful (Geller, 1993; Sullivan, 2004).

There are numerous advantages to a videotaping policy, which should create a more effective safety net. First, the presence of a camera will likely deter interrogators from using the most egregious, psychologically coercive tactics. Second, videotaping will deter frivolous defense claims of coercion where none existed. Third, a videotaped record provides an objective and accurate account of all that transpired, a common source of dispute that results from some combination of forgetting and self-serving distortions in memory. Questions about whether rights were administered and waived, whether the suspect was cooperative or evasive, whether detectives physically intimidated the suspect, whether promises or threats were made or implied, and whether the details in a confession emanated from the police or suspect are among the many issues that become resolvable. This should increase the fact-finding accuracy of judges and juries. For all these reasons, a mandatory videotaping requirement has many advocates (Cassell, 1996; Drizin \& Colgan, 2001; Gudjonsson, 2003; Kassin, 2004b; Leo, 1996b; Slobogin, 2003; Sullivan, 2004).

As a matter of policy, it is important not only that entire sessions be recorded but that the camera adopt a neutral "equal focus" perspective that shows both the accused and his or her interrogators. In an important program of research on illusory causation effects in attribution, Lassiter and his colleagues have found that people are more attuned to the situational factors that elicit confessions when the interrogator is visible on camera than when the focus is solely on the suspect (Lassiter \& Geers, 2004; Lassiter, Geers, Munhall, Handley, \& Beers, 2001; Lassiter \& Irvine, 1986). Under these circumstances, juries make more informed judgments of voluntariness and guilt when they see not only the final confession but the conditions that prompted it and the source of the details that it contained (Lassiter, Geers, Handley, Weiland, \& Munhall, 2002).

${ }^{3}$ The U.S. Supreme Court has stated that the exclusion of confessions judged involuntary serves a "complex of values," such as the desire to ensure that statements are reliable, to protect a defendant's due process rights, and to deter repugnant police practices that will undermine the public's trust in government (Blackburn v. Alabama, 1960). Recognizing that interrogation is necessary for law enforcement and crime control purposes, the present argument is driven by strictly pragmatic concerns for reliability.

${ }^{4}$ In Commonwealth v. DiGiambattista (2004), the Supreme Judicial Court of Massachusetts stopped just short of a mandatory videotaping requirement by ruling that any confession resulting from an unrecorded interrogation will entitle the defendant to a jury instruction that urges caution in the use of that confession. 


\section{REFERENCES}

Akehurst, L., \& Vrij, A. (1999). Creating suspects in police interviews. Journal of Applied Social Psychology, 29, 192-210.

Baldwin, J. (1993). Police interviewing techniques: Establishing truth or proof? British Journal of Criminology, 33, 325-352.

Bedau, H. A., \& Radelet, M. L. (1987). Miscarriages of justice in potentially capital cases. Stanford Law Review, 40, 21-179.

Bem, D. J. (1966). Inducing belief in false confessions. Journal of Personality and Social Psychology, 3, 707-710.

Blackburn v. Alabama, 361 U.S. 199 (1960).

Blackstone, W. (1765-1766). Commentaries on the laws of England. Oxford, England: Clarendon Press.

Blagrove, M. (1996). Effects of length of sleep deprivation on interrogative suggestibility. Journal of Experimental Psychology: Applied, 2, $48-59$.

Bull, R. (1989). Can training enhance the detection of deception? In J. C. Yuille (Ed.), Credibility assessment (pp. 83-99). London: Kluwer Academic

Bull, R., \& Milne, B. (2004). Attempts to improve the police interviewing of suspects. In G. D. Lassiter (Ed.), Interrogations, confessions, and entrapment (pp. 181-196). New York: Kluwer Academic.

Buller, D. B., Strzyzewski, K. D., \& Hunsaker, F. G. (1991). Interpersonal deception: II. The inferiority of conversational participants as deception detectors. Communication Monographs, 58, 25-40.

Cassell, P. G. (1996). Miranda's social costs: An empirical reassessment. Northwestern University Law Review, 90, 387-499.

Cassell, P. G. (1999). The guilty and the "innocent": An examination of alleged cases of wrongful conviction from false confessions. Harvard Journal of Law and Public Policy, 22, 523.

Chartrand, T. L., \& Bargh, J. A. (1999). The chameleon effect: The social perception-behavior link and social interaction. Journal of Personality and Social Psychology, 76, 893-910.

Cialdini, R. B. (2001). Influence: Science and practice (4th ed.). Needham Heights, MA: Allyn \& Bacon.

Cloud, M., Shepherd, G. B., Barkoff, A. N., \& Shur, J. V. (2002). Words without meaning: The Constitution, confessions, and mentally retarded suspects. University of Chicago Law Review, 69, 495-624.

Clymer, S. D. (2002). Are police free to disregard Miranda? Yale Law Journal, 112, 447-552.

Commonwealth v. DiGiambattista, slip op. SJC-09155 (August 16, 2004).

Connery, D. S. (Ed.). (1996). Convicting the innocent. Cambridge, MA: Brookline.

Conti, R. (1999). The psychology of false confessions. Journal of Credibility Assessment and Witness Psychology, 2, 14-36.

Culombe v. Connecticut, 367 U.S. 568 (1961).

Darley, J. M., \& Fazio, R. H. (1980). Expectancy confirmation processes arising in the social interaction sequence. American Psychologist, 35, 867-881.

Davis, D., \& Follette, W. C. (2002). Rethinking probative value of evidence: Base rates, intuitive profiling and the postdiction of behavior. Law and Human Behavior, 26, 133-158.

Davis, D., \& O'Donohue, W. (2003). The road to perdition: "Extreme influence" tactics in the interrogation room. In W. O'Donohue, P. Laws, \& C. Hollin (Eds.), Handbook of forensic psychology (pp. 897-996). New York: Basic Books.

DePaulo, B. M. (1994). Spotting lies: Can humans learn to do better? Current Directions in Psychological Science, 3, 83-86.

DePaulo, B. M., Lindsay, J. J., Malone, B. E., Muhlenbruck, L., Charlton, K., \& Cooper, H. (2003). Cues to deception. Psychological Bulletin, 129, 74-112.

DePaulo, B. M., \& Pfeifer, R. L. (1986). On-the-job experience and skill at detecting deception. Journal of Applied Social Psychology, 16, 249-267.

DePaulo, B. M., Stone, J. I., \& Lassiter, G. D. (1985). Deceiving and detecting deceit. In B. R. Schenkler (Ed.), The self and social life (pp. 323-370). New York: McGraw-Hill.

Dickerson v. United States, 120 S. Ct. 2326 (2000).

Drizin, S. A., \& Colgan, B. A. (2001). Let the cameras roll: Mandatory videotaping of interrogations is the solution to Illinois' problem of false confessions. Loyola University Chicago Law Journal, 32, 337-424.

Drizin, S. A., \& Colgan, B. A. (2004). Tales from the juvenile confessions front. In G. D. Lassiter (Ed.), Interrogations, confessions, and entrapment (pp. 127-162). New York: Kluwer Academic.

Drizin, S. A., \& Leo, R. A. (2004). The problem of false confessions in the post-DNA world. North Carolina Law Review, 82, 891-1007.

Ekman, P., \& O'Sullivan, M. (1991). Who can catch a liar? American Psychologist, 46, 913-920.

Ekman, P., O'Sullivan, M., \& Frank, M. G. (1999). A few can catch a liar. Psychological Science, 10, 263-266.

Faigman, D. L., Kaye, D. H., Saks, M. J., \& Sanders, J. (2002). Science in the law: Forensic science issues. St. Paul, MN: West.

Forrest, K. D., Wadkins, T. A., \& Miller, R. L. (2002). The role of preexisting stress on false confessions: An empirical study. Journal of Credibility Assessment and Witness Psychology, 3, 23-45.

Frazier v. Cupp, 394 U.S. 731 (1969).

Fulero, S. M. (2004). Expert psychological testimony on the psychology of interrogations and confessions. In G. D. Lassiter (Ed.), Interrogations, confessions, and entrapment (pp. 247-263). New York: Kluwer Academic.

Fulero, S. M., \& Everington, C. (1995). Assessing competency to waive Miranda rights in defendants with mental retardation. Law and Human Behavior, 19, 533-543.

Fulero, S. M., \& Everington, C. (2004). Mental retardation, competency to waive Miranda rights, and false confessions. In G. D. Lassiter (Ed.), Interrogations, confessions, and entrapment (pp. 163-179). New York: Kluwer Academic.

Garrido, E., Masip, J., \& Herrero, C. (2004). Police officers' credibility judgments: Accuracy and estimated ability. International Journal of Psychology, 39, 254-275.

Geller, W. A. (1993). Videotaping interrogations and confessions. $\mathrm{Na}$ tional Institute of Justice: Research in Brief. Washington, DC: U.S. Department of Justice.

Gilbert, D. T., \& Malone, P. S. (1995). The correspondence bias. Psychological Bulletin, 117, 21-38.

Gilovich, T., Savitsky, K., \& Medvec, V. H. (1998). The illusion of transparency: Biased assessments of others' ability to read one's emotional states. Journal of Personality and Social Psychology, 75, $332-346$.

Gordon, N., \& Fleisher, W. (2002). Effective interviewing and interrogation techniques. San Diego, CA: Academic Press.

Granhag, P. A., \& Strömwall, L. A. (Eds.). (2004). The detection of deception in forensic contexts. Cambridge, England: Cambridge University Press.

Grisso, T. (1981). Juveniles' waiver of rights: Legal and psychological competence. New York: Plenum Press.

Grisso, T. (1998). Forensic evaluation of juveniles. Sarasota, FL: Professional Resource Press.

Gross, S. R., Jacoby, K., Matheson, D. J., Montgomery, N., \& Patel, S. (2004). Exonerations in the United States from 1989 through 2003. Unpublished manuscript.

Gudjonsson, G. H. (1992). The psychology of interrogations, confessions, and testimony. London: Wiley.

Gudjonsson, G. H. (2002). Unreliable confessions and miscarriages of justice in Britain. International Journal of Police Science and Management, 4, 332-343.

Gudjonsson, G. H. (2003). The psychology of interrogations and confessions: A handbook. West Sussex, England: Wiley.

Harris v. New York, 401 U.S. 222 (1971).

Harrison, Y., \& Horne, J. A. (2000). The impact of sleep deprivation on decision making: A review. Journal of Experimental Psychology: Applied, 6, 236-249.

Hartwig, M., Granhag, P. A., Strömwall, L. A., \& Vrij, A. (2004). Police officers' lie detection accuracy: Interrogating freely vs. observing video. Police Quarterly, 7, 429-456.

Henkel, L. A., \& Coffman, K. J. (2004). Memory distortions in coerced false confessions: A source monitoring framework analysis. Applied Cognitive Psychology, 18, 567-588.

Holland, L., Kassin, S. M., \& Wells, G. L. (2005, March). Why suspects waive the right to a lineup: A study in the risk of actual innocence. Poster presented at the meeting of the American Psychology-Law Society, San Diego, CA.

Home Office. (1985). Police and Criminal Evidence Act of 1984. London: HMSO. 
Horselenberg, R., Merckelbach, H., \& Josephs, S. (2003). Individual differences and false confessions: A conceptual replication of Kassin and Kiechel (1996). Psychology, Crime, and Law, 9, 1-18.

Inbau, F. E., Reid, J. E., Buckley, J. P., \& Jayne, B. C. (2001). Criminal interrogation and confessions (4th ed.). Gaithersberg, MD: Aspen.

Jones, E. E. (1990). Interpersonal perception. New York: Freeman.

Kassin, S. M. (1997). The psychology of confession evidence. American Psychologist, 52, 221-233.

Kassin, S. M. (2002, November 1). False confessions and the jogger case. The New York Times, p. A31.

Kassin, S. M. (2004a). True or false: "I'd know a false confession if I saw one.” In P. A. Granhag \& L. A. Strömwall (Eds.), Deception detection in forensic contexts (pp. 172-194). Cambridge, England: Cambridge University Press.

Kassin, S. M. (2004b, April 26). Videotape police interrogations. The Boston Globe, p. A13.

Kassin, S. M., \& Fong, C. T. (1999). "I'm innocent!" Effects of training on judgments of truth and deception in the interrogation room. Law and Human Behavior, 23, 499-516.

Kassin, S. M., Goldstein, C. J., \& Savitsky, K. (2003). Behavioral confirmation in the interrogation room: On the dangers of presuming guilt. Law and Human Behavior, 27, 187-203.

Kassin, S. M., \& Kiechel, K. L. (1996). The social psychology of false confessions: Compliance, internalization, and confabulation. Psychological Science, 7, 125-128.

Kassin, S. M., \& McNall, K. (1991). Police interrogations and confessions: Communicating promises and threats by pragmatic implication. Law and Human Behavior, 15, 233-251.

Kassin, S. M., Meissner, C. A., \& Norwick, R. J. (in press). "I'd know a false confession if I saw one": A comparative study of college students and police investigators. Law and Human Behavior.

Kassin, S. M., \& Neumann, K. (1997). On the power of confession evidence: An experimental test of the "fundamental difference" hypothesis. Law and Human Behavior, 21, 469-484.

Kassin, S. M., \& Norwick, R. J. (2004). Why suspects waive their Miranda rights: The power of innocence. Law and Human Behavior, 28, 211-221.

Kassin, S. M., \& Sukel, H. (1997). Coerced confessions and the jury: An experimental test of the "harmless error" rule. Law and Human Behavior, 21, 27-46.

Kassin, S. M., \& Wrightsman, L. S. (1980). Prior confessions and mock juror verdicts. Journal of Applied Social Psychology, 10, 133-146.

Kassin, S. M., \& Wrightsman, L. S. (1985). Confession evidence. In S. M. Kassin \& L. S. Wrightsman (Eds.), The psychology of evidence and trial procedure (pp. 67-94). Beverly Hills, CA: Sage.

Koehnken, G. (1987). Training police officers to detect deceptive eyewitness statements: Does it work? Social Behavior, 2, 1-17.

Kopelman, M. D. (1999). Varieties of false memory. Cognitive Neuropsychology, 16, 197-214.

Lassiter, G. D. (Ed.). (2004). Interrogations, confessions, and entrapment. New York: Kluwer Press.

Lassiter, G. D., Clark, J. K., Daniels, L. E., \& Soinski, M. (2004, March). Can we recognize false confessions and does the presentation format make a difference? Paper presented at the meeting of the American Psychology-Law Society, Scottsdale, Arizona.

Lassiter, G. D., \& Geers, A. L. (2004). Evaluation of confession evidence: Effects of presentation format. In G. D. Lassiter (Ed.), Interrogations, confessions, and entrapment (pp. 197-214). New York: Kluwer Press.

Lassiter, G. D., Geers, A. L., Handley, I. M., Weiland, P. E., \& Munhall, P. J. (2002). Videotaped confessions and interrogations: A change in camera perspective alters verdicts in simulated trials. Journal of Applied Psychology, 87, 867-874.

Lassiter, G. D., Geers, A. L., Munhall, P. J., Handley, I. M., \& Beers, M. J. (2001). Videotaped confessions: Is guilt in the eye of the camera? Advances in Experimental Social Psychology, 33, 189-254.

Lassiter, G. D., \& Irvine, A. A. (1986). Videotaped confessions: The impact of camera point of view on judgments of coercion. Journal of Applied Social Psychology, 16, 268-276.

Latane, B. (1981). The psychology of social impact. American Psychologist, 36, 343-356.

Leo, R. A. (1996a). Inside the interrogation room. The Journal of Criminal Law and Criminology, 86, 266-303.
Leo, R. A. (1996b). Miranda's revenge: Police interrogation as a confidence game. Law and Society Review, 30, 259-288.

Leo, R. A. (2004). The third degree. In G. D. Lassiter (Ed.), Interrogations, confessions, and entrapment (pp. 37-84). New York: Kluwer Academic.

Leo, R. A., \& Ofshe, R. J. (1998). The consequences of false confessions: Deprivations of liberty and miscarriages of justice in the age of psychological interrogation. Journal of Criminal Law and Criminology, 88, $429-496$.

Leo, R. A., \& Ofshe, R. J. (2001). The truth about false confessions and advocacy scholarship. The Criminal Law Bulletin, 37, 293-370.

Leo, R. A., \& White, W. S. (1999). Adapting to Miranda: Modern interrogators' strategies for dealing with the obstacles posed by Miranda. Minnesota Law Review, 84, 397-472.

Lerner, M. J. (1980). The belief in a just world. New York: Plenum.

Loftus, E. F. (1979). Eyewitness testimony. Cambridge, MA: Harvard University Press.

Magid, L. (2001). Deceptive police interrogation practices: How far is too far? Michigan Law Review, 99, 1168-1210.

Mann, S., Vrij, A., \& Bull, R. (2004). Detecting true lies: Police officers' ability to detect suspects' lies. Journal of Applied Psychology, 89, 137-149.

Markman, S. J., \& Cassell, P. G. (1988). Protecting the innocent: A response to the Bedau-Radelet study. Stanford Law Review, 41, 121.

Masip, J., Alonso, H., Garrido, E., \& Anton, C. (in press). Generalized communicative suspicion (GCS) among police officers: Accounting for the investigator bias effect. Journal of Applied Social Psychology.

McCann, J. T. (1998). A conceptual framework for identifying various types of confessions. Behavioral Sciences and the Law, 16, 441-453.

McNatt, D. B. (2000). Ancient Pygmalion joins contemporary management: A meta-analysis of the result. Journal of Applied Psychology, 85, 314-322.

Meili, T. (2003). I am the Central Park jogger: A story of hope and possibility. New York: Scribner.

Meissner, C. A., \& Kassin, S. M. (2002). "He's guilty!”: Investigator bias in judgments of truth and deception. Law \& Human Behavior, 26, 469-480.

Meissner, C. A., \& Kassin, S. M. (2004). "You're guilty, so just confess!" Cognitive and behavioral confirmation biases in the interrogation room. In G. D. Lassiter (Ed.), Interrogations, confessions, and entrapment (pp. 85-106). New York: Kluwer Press.

Memon, A., Vrij, A., \& Bull, R. (2003). Psychology and law: Truthfulness, accuracy and credibility. London: Jossey-Bass.

Michigan v. Harvey, 494 U.S. 344 (1990).

Milgram, S. (1974). Obedience to authority: An experimental view. New York: Harper \& Row.

Miller, D. T., \& McFarland, C. (1987). Pluralistic ignorance: When similarity is interpreted as dissimilarity. Journal of Personality and Social Psychology, 53, 298-305.

Miranda v. Arizona, 384 U.S. 336 (1966).

Missouri v. Johnson, No. 98-5364 (2001).

Missouri v. Seibert, No. 02-1371 (2004).

Moston, S., Stephenson, G. M., \& Williamson, T. M. (1992). The effects of case characteristics on suspect behaviour during questioning. British Journal of Criminology, 32, 23-40.

Moston, S., Stephenson, G. M., \& Williamson, T. M. (1993). The incidence, antecedents and consequences of the use of the right to silence during police questioning. Criminal Behavior and Mental Health, 3, $30-47$.

Nawrat, I. R. (2001). Dialogue involvement as a social influence technique. Personality and Social Psychology Bulletin, 27, 1395-1406.

New York v. Quarles, 467 U.S. 649 (1984).

New York v. Wise, Richardson, McCray, Salaam, \& Santana: Affirmation in Response to Motion to Vacate Judgment of Conviction, Indictment No. 4762/89 (December 5, 2002).

Nickerson, R. S. (1998). Confirmation bias: A ubiquitous phenomenon in many guises. Review of General Psychology, 2, 175-220.

Oberlander, L. B., \& Goldstein, N. E. (2001). A review and update on the practice of evaluating Miranda comprehension. Behavioral Sciences and the Law, 19, 453-471.

Ofshe, R. J., \& Leo, R. A. (1997). The social psychology of police 
interrogation: The theory and classification of true and false confessions. Studies in Law, Politics, and Society, 16, 189-251.

O'Sullivan, M., \& Ekman, P. (2004). The wizards of deception detection. In P. A. Granhag \& L. A. Strömwall (Eds.), Deception detection in forensic contexts (pp. 269-286). Cambridge, England: Cambridge University Press.

Philipsborn, J. T. (2001, January/February 2001). Interrogation tactics in the post-Dickerson era. The Champion, pp. 18-22, 75-78.

Porter, S., Woodworth, M., \& Birt, A. R. (2000). Truth, lies, and videotape: An investigation of the ability of federal parole officers to detect deception. Law and Human Behavior, 24, 643-658.

Redlich, A. D. (2004). Mental illness, police interrogations, and the potential for false confession. Law and Psychiatry, 55, 19-21.

Redlich, A. D., \& Goodman, G. S. (2003). Taking responsibility for an act not committed: Influence of age and suggestibility. Law and Human Behavior, 27, 141-156.

Redlich, A. D., Silverman, M., Chen, J., \& Steiner, H. (2004). The police interrogation of children and adolescents. In G. D. Lassiter (Ed.), Interrogations, confessions, and entrapment (pp. 107-125). New York: Kluwer Academic.

Rimer, S. (2002, February 6). Convict's DNA sways labs, not a determined prosecutor. The New York Times, p. A14.

Rosenthal, R., \& Jacobson, L. (1968). Pygmalion in the classroom: Teacher expectation and pupils' intellectual development. New York: Holt, Rinehart \& Winston.

Ross, L. (1977). The intuitive psychologist and his shortcomings: Distortions in the attribution process. Advances in Experimental Social Psychology, 10, 174-221.

Russano, M. B., Miessner, C. A., Narchet, F. M., \& Kassin, S. M. (in press). Investigating true and false confessions within a novel experimental paradigm. Psychological Science.

Saulny, S. (2002, December 8). Why confess to what you didn't do? The New York Times, Section 4, p. 5.

Scheck, B., Neufeld, P., \& Dwyer, J. (2000). Actual innocence. Garden City, NY: Doubleday.

Slobogin, C. (2003). Toward taping. Ohio State Journal of Criminal Law, $1,309-322$.

Snyder, M. (1992). Motivational foundations of behavioral confirmation. Advances in Experimental Social Psychology, 25, 67-114.

Snyder, M., \& Stukas, A. (1999). Interpersonal processes: The interplay of cognitive, motivational, and behavioral activities in social interaction. Annual Review of Psychology, 50, 273-303.

Snyder, M., \& Swann, W. B., Jr. (1978). Hypothesis-testing processes in social interaction. Journal of Personality and Social Psychology, 36, $1202-1212$.
Softley, P. (1980). Police interrogation: An observational study in four police stations. London: Home Office Research Study, Royal Commission on Criminal Procedure Research Study.

Sullivan, T. (1992). Unequal verdicts: The Central Park jogger trials. New York: Simon \& Schuster.

Sullivan, T. P. (2004). Police experiences with recording custodial interrogations. Evanston, IL: Northwestern University School of Law, Center on Wrongful Convictions.

United States v. Hall, 974 F. Supp. 1198 (1997).

Vrij, A. (1994). The impact of information and setting on detection of deception by police detectives. Journal of Nonverbal Behavior, 18, $117-132$.

Vrij, A. (2000). Detecting lies and deceit: The psychology of lying and the implications for professional practice. London: Wiley.

Vrij, A. (2004). Why professionals fail to catch liars and how they can improve. Legal and Criminal Psychology, 9, 159-181.

Vrij, A., Edward, K., \& Bull, R. (2001). Police officers' ability to detect deceit: The benefit of indirect deception detection measures. Legal and Criminological Psychology, 6, 185-197.

Vrij, A., \& Mann, S. (2001). Who killed my relative? Police officers' ability to detect real-life high-stake lies. Psychology, Crime, and Law, 7, 119-132.

Walters, S. (2003). Principles of kinesic interview and interrogation (2nd ed.). Boca Raton, FL: CRC Press.

Weisselberg, C. D. (2001). In the stationhouse after Dickerson. Michigan Law Review, 99, 1121-1167.

Wells, G. L. (2003). Murder, extramarital affairs, and the issue of probative value. Law and Human Behavior, 27, 623-627.

Wells, G. L., Malpass, R. S., Lindsay, R. C. L., Fisher, R. P., Turtle, J. W., $\&$ Fulero, S. M. (2000). From the lab to the police station: A successful application of eyewitness research. American Psychologist, 55, 581-598.

White, W. S. (2003). Miranda's waning protections: Police interrogation practices after Dickerson. Ann Arbor: University of Michigan Press.

Wrightsman, L. S., \& Kassin, S. M. (1993). Confessions in the courtroom. Newbury Park, CA: Sage.

Zimbardo, P. G. (1967, June). The psychology of police confessions. Psychology Today, 1, 17-20, 25-27.

Zuckerman, M., DePaulo, B. M., \& Rosenthal, R. (1981). Verbal and nonverbal communication of deception. Advances in Experimental Social Psychology, 14, 1-59.

Zuckerman, M., Koestner, R., \& Alton, A. O. (1984). Learning to detect deception. Journal of Personality and Social Psychology, 46, 519-528. 